FIMAL PERFDRMAMCE REPDRT

$$
\text { DF }
$$

GRAMT DE-FGO1-BSCE-15301

RADIANT ENERGY POWER SOURCE FOR JET AIRCRAFT

FEBRUARY 1992 
FIMAL PERFORMAMCE REPDRT

GRAMT DE-FGO1-BSCE-15301

\title{
RADIANT ENERGY POWER SOURCE FOR JET AIRCRAFT
}

\section{By}

\author{
o. L. Doel1ner \\ DISCLAIMER
}

This report was prepared as an account of work sponsored by an agency of the United States Government. Neither the United States Government nor any agency thereof, nor any of their employees, makes any warranty, express or implied, or assumes any legal liability or responsibility for the accuracy, completeness, or usefulness of any information, apparatus, product, or process disclosed, or represents that its use would not infringe privately owned rights. Reference herein to any specific commercial product, process, or service by trade name, trademark, manufacturer, or otherwise does not necessarily constitute or imply its endorsement, recommendation, or favoring by the United States Government or any agency thereof. The views and opinions of authors expressed he, ein do not necessarily state or reflect those of the United States Government or any agency thereof.

\section{MISUER}

FEBRUARY 1992

DE. IION OF THIS DOCUMENT IS NAWHA... 


\section{ACKNOWLEDGEMENTS}

Acknowledgement is expressed to the NBS/DOE office of Energy Related Inventions for their support and funding of Grants DE-FGO1-82CE-15144 and DE-FGO1-86CE-15301.

Acknowledgement is expressed to Williams Air Force Base (Arizona) for their support on Grants DE-FG01-82CE-15144 and DE-FG01-86CE-15301.

Acknowledgement is also expressed to the many other affiliations and individuals who have been cooperative and helpful on this overall project. 
TABLE OF CONTENTS

Page

ABSTRACT . . . . . . . . . . . . . . . . . . . . 4

1. INTRODUCTION . . . . . . . . . . . . . . . . . 5

Early History . . . . . . . . . . . . . 5

Overall Multilateral Approach . . . . . . . . . 7

Overview of Phase I: Grant DE-FG01-82CE-15144. 9

2. DISCUSSION OF PHASE II:

GRANT DE-FG01-86CE-15301 . . . . . . . . 12

General .................... 12

Discussion of Photouoltaic Cells......... . 18

3. GENERAL DISCUSSION . . . . . . . . . . . . . . 23

4. HISTORICAL PERSPECTIVE AND SUMMARY . . . . . . . 29

5. CONCLUSION . . . . . . . . . . . . . . . . . 35

LIST OF REFERENCES . . . . . . . . . . . . . . . 37 
ABSTRACT

This report begins with a historical overview on the origin and early beginnings of Radiant Energy Power Source for Jet Aircraft. The report reviews the work done in Phase 1 (Grant DE-FG01-82CE-15144) and then gives a discussion of Phase II (Grant DE-FG01-86CE-15301). Included is a reaconably detailed discussion of photovoltaic cells and the research and development needed in this area. The report closes with a historical perspective and summary related to situations historicaliy encountered on projects of this nature. 
FINAL PERFORMANCE REPORT

of

GRANT DE-FG01-86CE-15301

RADIANT ENERGY POWER SOURCE FOR JET AIRCRAFT

CHAPTER 1

INTRODUCT I ON

\section{Early History}

The overall program of Radiant Energy Power Source for Jet Aircraft began in approximately 1976 when grantee organization studied the concept of emploring photovoltaic cells in proximity with combustion liners in jet aircraft to generate electrical power for the aircraft. This led to a patent application (patent issuing in 1978) and a graduate thesis at the University of Arizona in 1979. The first major public display of this project was made on February 11-12, 1984, at the Mational Inventors Expo' 84 at the U.S. Patent and Trademark Office in Arlington, Virginia. 
In August 1979 a grant was applied for from the NBS/DOE Office of Energy Related Inventions. There were 4 main areas of concern:

1) It was thought that the jet-engine environment might be too hot for the photovoltaic cells. There was apparently some confusion on exactly how the photovaltaic cells were to be assembled and cooled in the jet engine. This assembly is simple, but critical, and was apparently neither obvious nor understood.

2) It was questioned that the photovoltaic cells could produce sufficient power to be commensurate with existing systems (alternators and generators).

3) It was thought that carbon soot from the combustion flame might obscure the covers (sapphire windows) over the photovoltaic cells.

1 This was understandable due to the degree of nonobuiousness of this concept-this is actually outstanding testimony to the fact that this project was extremely nonobuious. 
4) It was not seen how the photovoltaic cells could be assembled and mounted inside the jet engine, with provisions for external connections. (i.e., how cell connections, windows, and substrates could actually be fabricated in a jet engine.)

In early 1981, a full size (18" diameter) mock-up was constructed using surplus G.E. J-85 engine parts and simulated photovaltaic cells. This mock-up was important in showing that cell connections, windows, and substrates could actually be fabricated. It was this mock-up that was displared at the National Inventors Expo' 84 mentioned above.

The Phase I Grant DE-FG01-82CE-15144 was allowed in 1982. The above subjects (areas of concern) are further discussed, as applicable, later in this report. These subjects are also addressed, in detail, in Doellner, 1991.

\section{Guerall Multilateral Appraach}

$\mathbf{D}$

From the very onset of this project in approximately 1976, an overall multilateral approach has been followed. Preceding and simultaneous to Grants DE-FGO1-82CE-15144 and DE-FG01-86CE-15301, a rigorous independent parallel effort of 
analytical and theoretical work has proceeded on this project. The concept has been looked at from every theoretical and analytical perspective. Such approaches are extremely powerful, as they fail only by overlooking some aspect of the theory, not from faults in the theory. Much of this effort was done in conjunction with graduate work at the University of Arizona. One aduantage of doing this work in conjunction with a University is that the work can be published as a thesis and/or dissertation under the University. This greatly helps in establishing credibility. Universities would not allow such publications, if they did not agree with and effectively endorse the contents, or if there were any technical inaccuracies. Many theses and dissertations are later published in professional journals and/or as books. If an organization or individual tried to publish without such a strong backing, the road could be difficult, particularly on a project of such a radically different nature as Radiant Energy Power Source for Jet Aircraft. 
Querview of Phase I: Grant DE-FGO1-82CE-15144

Phase I Grant DE-FGO1-82CE-15144 found the magnitude and geometry of $f l a m e$ radiation inside a jet engine, as a function of engine operating conditions. This was important because prior to approximately 1982 (when Grant DE-FG01-82CE-15144 issued) very little data on this subject was available. This data was critically important because if the radiation were not available, than adequate electrical power levels could not be obtained, and the concept would be invalid. The radiation levels were found to be more than adequate, in fact, with considerable reserves. This is particularly true because photovoltaic cells are improving.

There were three primary reasons why Phase I took considerable time. One reason was that the testing and work (in general) at Air Force facilities was being done on a noninterference basis, meaning that all normal Air Force activity proceeded first.

The second primary reason was encountered in the initial obtaining of Grant DE-FG01-82CE-15144 and also during the actual performance of both Phase I (Grant DE-FG01-82CE-15144) and Phase II (Grant DE-FG01-86CE-15301). It is mentioned here because many people are not even aware of this potential 
problem. Many people perceived this project as being very difficult to believe because of its radically different nature. One must be very gentle dealing with these people, gradually educating them as the project proceeds. The same was true when this concept was introduced to the University of Arizona in approximately 1977, i.e., these University professors also initially found this project verydifficult to believe. Much time has been spent gently appraaching and educating those who may have reacted entirely differently if they were not approached so carefully. This project apparently contradicts normal intuition, many highly-educated people have initially found this concept very difficult to accept. In the cases of Williams Air Force Base and the University of Arizona, the project gradually acquired acceptance. In fact, excellent relationships and contacts have been established at both Williams Air Force Base and the University of Arizona.

A third primary reason was funding. To a certain extent, a shortage of funds is effectively a shortage of power. It is sometimes very hard to motivate individuals and/or companies when the available money is limited.

Grant DE-FG01-82CE-15144 resulted in a very carefully prepared 101 page (single-spaced) report, with 
13 supplementary photographs. Strong reports are necessary and essential for concepts of this nature. The testing involved in Grant DE-FG01-82CE-15144 involved considerable equipment expenseg ${ }^{2}$ and the testing and report took extensive preparation and time. In due respect, on a project of this nature one can only accept and be deeply appreciative of any help one can get. However, it is not sure how it was thought that Phase I could be done for $\$ 10,000$. Phase I resulted in a monetary deficit that had to extend into Phase II. It is believed that Phase I and this overall project were (understandably) ${ }^{3}$ grossly oversimplified in the early years of this project by almost everyone. It is believed that the listing of references shown in the List of References will help to show the overall depth, involvement, and complexity of this project. If the direct low-bandgap photovoltaic cells. (GaSb) were obtained in Phase II, the Phase II testing would have had to be done largely on funds of grantee organization (with a minimum investment by grantee organization of many tens of thousands of dollars).

2 The equipment expenses involved in Grant DE-FG01-82CE15144 exceeded the funding level of the grant.

3 This was understandable-and evident in numerous personal contacts of this investigator with individuals/affiliations from every background and discipline. 
CHAPTER 2

DISCUSSION OF PHASE II: GRANT DE-FG01-86CE-15301

\section{General}

Considering the effort that has gone into photovoltaiccell research, it seems a little difficult to believe that at the onset of Phase II there really were not any good direct low-bandgap photovoltaic cells available. Contact with John Cape and Dr. Lewis Fraas at Ches on Research in Richmond, California prior to Phase II indicated that they were doing research on gallium antimonide (GaSb). Cheuron Research indicated that white these cells are theoretically viable, they have not, in general, been built except in very 1 imited experimental quantities. This work at Cheuron Research apparently ceased when their principal investigator Dr. Lewis M. Fraas changed employment to the Boeing Company in Seattle, Washington. The original plans of obtaining the Gasb cells from Cheuron Research had to be changed to obtaining the cells from the Boe ing Company. 
Attempts to get a few of these cells from Boeing at first seemed successful and in early 1990 all appeared well. At this time Williams Air Force Base was fully briefed and ready to support the planned testing. (The logistics involved in getting this set up was no small task.) However, on March 9 , 1990 a phone call was received from Rick Liechty of Boeing stating that a Boeing Vice President (Dr. Edith Martin) had canceled Boeing's shipment of Gasb photovoltaic cells to grantee organization.4

This situation was more complex and intricate than it superficially appears. The gallium arsenide (GaAs) photovoltaic cells for this grant were being built and provided by Mark S. Kuryla of Varian in Palo Alto, California. Mark Kuryla is a very close friend of Lewis Fraas (they used to work together). Before Boeing's vice president interposed on this project, Mark and this author had numerous phone conversations and Mark called approximately every other week (this was over a period of months). This was certainly the kind of desired environment and cooperation needed to aduance

4 Apparently, Dr. Edith Martin also found this concept very difficult to believe. (Once, this author's University professors reacted almost the same way.) Ai a later date (May 4, 1990) Dr. Martin reversed the cancellation and stated that the cells would be provided by Boeing however, the cells have never been provided. 
a project of the nature of Radiant Energy Power Source for Jet Aircraft. However, when Boeing's Vice President canceled Boeing's shipment of the Gasb cells, Mark's phone calls ceased. Meanwhile, Grant Project Officer Jack Aellen got involved attempting to work out an arrangement where the cells could be obtained from Bueing. 5 At this point it was apparent that it would have been both awkward and in vain to try to get the GaAs cells from Varian, since Mark Kuryla was obuiously waiting to see what Boeing was going to do. If Boeing provided the Gasb cells, then Mark would very quickly follow suit and provide the GaAs cells. Under these circumstances, obtaining the Gasb photouoltaic cells was also the key to obtaining the GaAs cells. Unfortunately, not obtaining the Gasb cells acted as an impasse to obtaining the GaAs calls. The priority in obtaining the Gasb photovoltaic cells had to be of the highest level; this becomes obvious when the theoretical aspects of these cells are understood, see the following section entitled Discussion of Photovoltaic Cells. 6

5 Per telephone conversation(s) with Jack Aellen, Boe ing (Rick Liechty) initially responded favorably and then ceased
to return any of his phone calls.

6 For a $2,000 \mathrm{~K}$ source the Gasb photovoltaic cells are 13.6\% efficient and the GaAs cells are $1.4 \%$ efficient. At lower flame temperatures (e.g.: 1 , $800 \mathrm{k}$ ) the $r \equiv t: 0$ becomes more spectacular-11.2\% (GaSb) versus $0.7 \%$ (GaAs). 
Arrangements could have been made in obtaining GaAs photovoltaic cells from other sources, however, if Boeing came through-as expected-this would be a redundant effort. of greater importance is that if this got back to Varian ii.e., getting GaAs cells from other sources), then Varian would have felt slighted (if not insulted). I' was sincerely believed that Boeing was going to provide the Gasb photovoltaic cells.? There is no exclusivity to direct law-bandgap photovoltaic cells except that applications are so limited at the present time that very few people are doing research in this area. For example, if exclusivity is held for Gasb photouoltaic cells, there is certainly no exclusivity for numerous other direct low-bandgap photovoltaic cells that are technologically capable of being built. Direct law-bandgap photovoltaic cells will someday be-in general-as available as silicon and/or GaAs cells are today, if applications for them exist. For example, there are numerous combinations (binary, ternary, quaternary, etc.) of elements from the II-UI and III $U$ columns of the periodic table capable of being developed into useful direct low-bandgap photovoltaic cells for use in this project.

7 Government grants are for investigating technological areas the government feels needs to be researched for the general benefit of this country. Most companies cooperate with government grants. 
Many of these (periodic-table) elements are widely available. Research in this area is strongly needed. These cells are virtually totally undeveloped mainly because the emphasis of the photovoltaic-cell community has been on cells for terrestrial and space (solar-spectrum) applications. These cells have only been researched to a limited degree, mainly as a means of increasing terrestrial and space performance (e.g., in solar-application tandem stacks).

When Lewis Fraas was reached by telephone on April 22, 1991 by grantee organization, ${ }^{8}$ it was politely indicated that some resolution was needed if for any reason Boeing could not supply the GaSb cells for Grant DE-FG01-86CE-15301, then alternate arrangements needed to be made.9 This author was again strongly assured by Lewis Fraas at least-that Boeing would supply these cells. In fact, to date, neither this author or Jack Aellen ever heard from Boeing ${ }^{10}$ that Boeing

8 After grant reinstatement-Grant DE-FG01-86CE-15301 lapsed March 27, 1990.

- However, after grant reinstatement, gearing up to obtain alternate cells and rescheduling Air Force facilities would have taken more time than was remaining-if the grant wasn't extended.

10 After the Boeing Vice President reversed the March 9 , 1990 cancellation. 
wouldn't provide the cells. The cells were always going to be provided, but months passed and they never were.

If Boeing had indicated $r i g h t$ up front that for any of several reasons they couldn't provide the Gasb cells, then some kind of alternate arrangements could have been made."l What made the situation extremely difficult was that Boeing goes on for months under the premise that GaSb photovoltaic cells will be provided and then never provides them. Both Boeing and Varian insisted on giving these cells-neither wanted to bother with purchase requisitions. The time and effort being spent on just the correspondence and logistics of trying to obtain these cells became overwheiming. It is obuious, that any reduction to practice of this project must overcome and/or bypass these obstacles/barriers-a certain amount of cooperation is essential. No patents and/or patent applications were conceived or reduced to practice under the terms of Grant DE-FG01-86CE-15301. In fact, unless this overall project starts progressing at a more favorable pace, it is questionable whether it is even aduisable to obtain and or maintain patents. Many companies are firm aduocates of

11 Although, wi thout good direct low-bandgap photovoltail: cells auailable, only limited tests could have been run. 
the not-inuented-here syndrome. Under these circumstances, patents can be more of a deterient than an attribute.

\section{Discussion of Photouoltaic Cells}

Photovoltaic cells are needed that are matched to jetengine combustion spectrums, not photovoltaic cells matched to solar spectrums. GaAs and silicon photovoltaic cells are matched to solar spectrums, they alone do not build the foundation of a good test. The whole concept of Radiant Energy Power Source for Jet Aircraft is based on the use of direct low-bandgap photovoltaic cells-cells matched to combustion-flame spectrums. This has been known since (and before) 1981. Doellner, 1981, p. 9 states: "...the optimum photovoltaic cell for this application will be a direct bandgap semiconductor (for lowest temperature sensitivity) with a bandgap an the order of 0.3 to 0.8 e.V. (for a good spectral match to the combustion-flame spectrum)."

GaAs has an extremely high bandgap for use in this project. Silicon also has a high bandgap, and additionally is an indirect-bandgap photovoltaic cell with a resulting undesirable low optical absorption coefficient (resulting in 
thick photovoltaic (ells) and unwanted falloff in quantum efficiency for wavelengths longer than about $900 \mathrm{~nm}$.

Neither silicon or GaAs fulfill the objectives stated in the 1981 NBS Evaluation Report. They do not have even close to the specified $101: 015 \%$ efficiency to combustion-flame sources. The NES Evaluation Report (see page 2 in the Introduction writter by T. A. Coultas of NBS/OERI) states: -Perhaps foremost is that the cells will perform as expected. The cells must have an efficiency on the order of 10 to $15 \%$, and although this is nominal for solar powered cells, the cells exposed to the blackbody of the combustion chamber must al so attain these efficiencies." Using the tables and methods in Appendix A of Doellner, 1991, the maximum efficiency for GaAs photovoltaic cells for a $2,000 \mathrm{~K}$ source would be an unacceptable 1.4\%. For silicon photovol taic cells the maximum efficiency for a $2,000 \mathrm{~K}$ source would be an unacceptable $3.1 \%$. Conversely, for 0.7 e.U. photovoltaic cells the efficiency would be an acceptable $13.6 \%(2,000 \mathrm{~K}$ source $)$. For 0.4 e.v. photovoltaic cells the efficiency would be an even higher $22.3 \%$ (same $2,000 \mathrm{~K}$ source). It is of interest, that at lower $f l a m e$ temperatures $(e .9 ., 1,700 \mathrm{~K})$, the efficiency of the 0.4 e.V. photovoltaic cells is over double that of the 0.7 e.U. photovoltaic celis. It is also of interest that 
while the 0.7 e.V. photovoltaic cells drop in efficiency fior lower flame temperatures, the efficiency of the 0.4 e.U. celis remains very much the same for all flame temperatures between 1,700 and $2,500 \mathrm{~K}$. The photovoltaic cells with bandgaps of 0.4 e.V. have calculated efficiencies over $21 \%$ for all flame temperatures from 1,700 to 2,500 K (Doellner, 1991).

Neither silicon or GaAs extend in response even close to 1.2 microns, the desired spectral response given in the NBS Evaluation Report and specified in the Grant DE-FG01-86CE-15301 (Attachment A) Project Summary. The response for silicon or GaAs photovoltaic cells in the spectral region from 1,000 to $1,200 \mathrm{~nm}$ to combustion flame spectrum is virtually nil. The 1,000 to $1,200 \mathrm{~nm}$ spectral interval is an extremely important spectral interval for combustion-flame spectra, as are all spectral regions-in general-at wavelengths longer than about $1,000 \mathrm{~nm}$. For a $2,000 \mathrm{k}$ source, there is about 35 times the radiant energy in the $200 \mathrm{~nm}$ spectral interval from 1,000 to $1,200 \mathrm{~nm}$, as in the $200 \mathrm{~nm}$ spectral interval from 400 to $600 \mathrm{~nm}$. This may easily be seen on a blackbody sliderule or from the values given in Column 5, Table 15, Appendix A, Doeliner, 1991. CConversely, it is of interest that for solar spectrums where the radiation peaks at about $550 \mathrm{~nm}$, there is about 34 times the radiation in the 400 to $600 \mathrm{~nm}$ spectral 
interual as in the 1,000 to $1,200 \mathrm{~nm}$ spectral interval. Use Column 5, Table 21, Appendix A, Doellner, 1991.)

At best, silicon and GaAs photovoltaic cells are supplementary secondary cells for this project. This has been known from the very beginning (Doellner, 1981, p. 9). The value of tying up major Air Force facilities and time to rur a test with (only) photovoltalc cells known to be optimized for solar spectrums is questionable.12 As the preceding discussion vividly shows (see also Doellner, 1991), the main primary photovoltaic cells for this project are direct lowbandgap photovoltaic cells.

Indirect low-bandgap photovoltaic cells like germanium also have undesirable gradual absorption edges.13 While such indirect-bandgap cells may be useful as the bottom cell in tandem stacks for solar spectrums, their application in this project is probably limited. This is because of the intense radiation in combustion-flame spectra between approximately 1,400 and $1,700 \mathrm{~nm}$, the corresponding poor response of germanium in this spectral region, and other reasons

12 Very little (if anything) would be learned that is not a) ready known.

13 See absorption coefficient versus e.V. curves for germanium in Omar, 1975, P. 295; compare with direct-bandgap

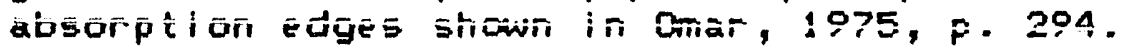


associated with indirect-bandgap photovoltaic cells, see Doellner, 1991, p. 25-26.

Contact was made with Dr. Lewis Fraas at the 22nd IEEE Photovaltaic Specialist Conference in Las Vegas, Nevada on October 8, 1991. Dr. Fraas stated that he could provide the Gasb photovoltaic cells, the main problem being that some minor packaging is involved. However, while at the conference Dr. Fraas introduced the undersigned to William (Ed) Horne of Boeing who stated that his group could do this packaging. This packaging amounts to interfacing the Gasb celi(s) with the photovoltaic-cell test structure(s).

A grant extension was applied for CLetter: 0 . L. Doellner to P. P. Morgan, $8 / 14 / 91$ ) but the extension request was not accepted. It was not certain that Boeing would have cooperated on this grant if the grant was extended. 
CHAPTER 3

\section{GENERAL DISCUSSION}

It is ironic, considering the amount of money and effo.t that has gone into photovaltaic-cell research, that it should be difficult to obtain certain photovoltaic cells. It is sincerely believed that there are many companies cincluding small companies) capable or building direct low-bandgap photovaltaic cells that would be delighted to cooperate with this project. For example, it has been known for years that direct low-bandgap photovoltaic cells with bindgixps from about 0.4 to $0.7 \mathrm{e.V}$. (or higher) can be constructed from InGaAsp (more specifically $\operatorname{In}_{1-x} G a_{x} A s_{1-y} P_{y}$ ). Indium and phosphide are inexpensive raw materials. It is not believod that these cells would be significantly more expensive than GaAs or Gasb photovoltaic cells. As already mentioned, many other types of direct low-bandgap photovoltaic cells are theoretically viable.

Grant DE-FG01-86CE-15301 was certainly worthwhile and vividly demoristrates that a reduction to practice of this project is much more involved than-at least some-originally anticipated. This is also shown in Doellner, 1991-this 
dissertation is, at least in part, a discussion of work needed to be done on this project. For example, the structure shown in Figures 3.3 and 3.4 of this dissertation needs to be constructed and full-scale tests run. While extensive work is involved, the work could move very rapidly if direct lowbandgap photovoltaic cells were available.

While not superficially apparent, the development of this project could be done cost effectively and aduantageously as a small business. This would certainly bypass some of the perils and pitfalls sometimes associated with bureaucracies. For example, surplus G.E. J-85 engines and parts are easily obtained. Cother engines could be used with suitable modification to their combustors.) Doellner, 1991, p. 58-59 discusses how a phatovaltaic power-generating structure (centertrame structure with assembled photovoltaic cells) could be constructed using even modest machine-shop facilities. Discussions with machine shops by grantee organization indicate that this can easily be done using mainly milling facilities. The only known obstacle is the present non-availability of direct low-bandgap photovoltaic cells. As already mentioned, it is sincerely believed that there are many companies (including small companies) capable of building direct low-bandgap photovoltaic cells that would 
be delighted to cooperate with this project. Sooner or later direct low-bandgap photovaltaic cells will be commercially available-even Gasb cells. The suppliers and/or subcontractors for such cells should be integrated directly into any future grant document(s).

Early concerns regarding the possibility of carbon soot forming on the photovoltaic-cell covers (sapphire windows) were largely unfounded. Phase I found absolutely no evidence of carbon soot forming on the fiber optic probes (Doellner, 1986), and these fiber optic probes were projecting considerably closer to the combustion $f l$ ame than the nominal location of photovoltaic-cell covers. From Phase I and other recently published data, it is known that the radiant energy existing in jet engines is more than adequate even under certain known "difficult" conditions (as for example, during engine idiing). The physical/geometrical situation reduces to a simple arrangement of cooled photovoltaic cells in proximity with a known source. There is really not much that can go wrong with this kind of simple arrangement-the probability that this project does not work as theorized is virtually zero. Goad direct low-bandgap photovaltaic cells have been technically viable for years and are urgently needed. 
Under the present circumstances, one of the best things that could be done for this project would be to publish a book based on the 1991 dissertation (Doellner, 1991). This would further enhance credibility and also help to remove some of the stigma associated with this radically different concept. 14 Publishing a book based on the referenced Ph.D. dissertation should be relatively easy, while, without the dissertation, it may have been virtually impossible on a project of this nature. The book would be written (as is the dissertation) largely from the viewpoint of theoretical physics, rather than experimental physics, as would be the case if more experimental data were obtained. This project is theoretically pristine, 15 this investigator feels comfortable and confident in publishing a book on theoretical grounds. As already mentioned, theoretical approaches are extremely powerful, as they fail only by overlooking some aspect of the theory, not from faults in the theory. Many books are written from purely theoretical perspectives, as for example, books in

14 This is important if ongoing acceptance br the aviation establishment is to be obtained.

15 Grantee organization has researched this project full time (plus some) over 16 years (mainly on in-house funds) and has been unable to find any theoretical or other flaw in this project. 
astronomy on black holes and white dwarfs. Project continuity is important-waiting much longer will significantly delay this overall project. Sitting back and waiting for direct low-bandgap photovoltaic cells to appear will not aduance this project. (Standing still is a great way to get run over-Lee I acocca, 1992.)

It is planned that the preface of this proposed book will discuss that the book is written on largely theoretical grounds due to the non-availability of direct low-bandgap photovoltaic cells. In conjunction with this subject, the preface will discuss the strong need for photovoltaic cells with direct bandgaps from about 0.4 to 0.8 e.U..

The proposed book will demonstrate to researchers in the field that theme are large-scale applications for direct $10 w-$ bandgap photovoltaic cells, and will thus encourage work in this area. There is extremely little doubt that this project will not work exactly as proposed, however good direct lowbandgap photovoltaic cells are urgently needed. Without the book, there would probably be a highly undesirable period of relatively little actiuity, simply because good direct lowbandgap photovoltaic cells are not available and probably won't be developed (except on a limited scale) unless applications exist. 
Grantee organization can do continued in-house development of this project with a surplus gas-turbine engine. Grantee organization obuiously holds a strong motivation on this project, knowing the superiority of the concept over conventional methods.

This concept, while basically simple, was apparently very non-obuious, and otherwise should have been extensively studied over 25 years ago. The aduantages and technical viability of direct low-bandgap photovoltaic cells have long been known. Jet-engine $f l$ ame radiation was believed as being blackbody in nature for well over 25 years. The subject must not be swept under the rug, as was historically tried in the case of the jet engine (see Historical Perspective and Summary (hapter). This subject must be objectively siudied and researched. The proposed book will open an avenue for individuals and even lay readers to objectively understand this project. Criticism of projects of this nature is generally always due to people not versed in the many disciplines necessary to fully understand the underlying concepts. 
CHAPTER 4

HISTORICAL PERSPECTIUE AND SUMMARY

This project represents a radical change in direction, if not a contradiction of what the aviation community has been doing for years. In general, alternators and generators have been used in reciprocating (piston) and jet aircraft engines close to their inception. Some people in the auiation establishment may find Radiant Energy Power Source for Jet Aircraft disquieting as it contradicts long established conventions and or traditions.

If one studies the history books, for example, on the development of the jet engine, it is found that sir Frank Whit tle found the aviation establishment totally uninterested (and in fact strongly opposed) 16 to the jet engine. Historically, the aviation establishment reacted to Frank Whittle essentially like: "Doesn't this whittle gur think we

16 It must be remembered that many very useful inventionsóninouations in many yaried technological areas; such as for example, automobile seat beits and air bags, similarly were once violently opposed-at least by some. 
know how to build airplanes." To quote Gunston, 1986, p. 107 in reference to the development of the jet engine: -..neither Air Ministry nor British industry showed the slightest interest." Other authors (Anderson, 1978, p. 368) word this much stronger as "...staunch disinterest." Innumerable other books and references are available substantiating this historical overview. If it were not for the perseverance of Frank Whittle, Hans von Ohain (another extremely important contributor), and a few others, the aviation establishment would still be using reciprocating (piston) engines in aircraft, with none of the many beautiful advantages of jet-engine technology. As commonly known, the jet engine resulted in a profound revolution in aviation.

with this kind of historical background and precedence, it is difficult to believe that the aviation establishment would react differently to this project than they did to the jet engine. The common denominator of this project and the jet engine is the element of change-much of the aviation establishment is highly resistant to change. Anyone who necessarily expects a nice warm reception from all sectors of the aviation establishment on a project of this nature has not studied the history books. Considering these factors, 
remarkable cooperation has been achieved overall on this project-with few exceptions.

In general, such experiences are not unique to the aviation establishment, but are a fairly common plight of inventors. There is a poem written by Alan Ashley-Pitt entitled "The Inventor" that nicely summarizes what inventors go through. Only inventors that have "been there" will fully appreciate this poem. Attendance at several NBS/DOE Innovation Workshops and a DOE Commercialization Planning Workshop bring out that many inveritors frequently encounter similar experiences. Inventions and innovations involve change-many people are extremely resistant to change. This Historical Perspective chapter is included in this report because some-at least-are not even aware of these potential problems and the impact these problems may have on progress.

The very early knowledge of these historical problems is why Radiant Energy Power Source for Jet Aircraft was approached from an overall multilateral perspective.17 Obtaining a Ph.D. is not easy, however, the associated dissertation is certainly going to be most helpful to this project. (Other approaches may fail-this is probably little baske it.

17 The old adage says to never put all your eggs in one 
more than history repeating itself.) obtaining a Ph.D. involves considerable time and expense, however, the graduate dissertation Aircraft Photovoltaic Power-generating System is essentially a book. Writing a good, highly-original book involving considerable theoretical work typically takes 5 to 10 (or more) years. From this perspective, excellent progress has been made on this overall project. Phase I Grant DE-FGO182CE-15144 was most helpful, as previously discussed. Phase II Grant DE-FG01-86CE-15301 has been helpful in that it has brought out a problem, namely, in the present availability of good direct low-bandgap photovoltalc cells sultable for this project. These cells are unavailable because the emphasis of the photouoltaic-cell community has been on cells for terrestrial and space (solar spectrum) applications, as already discussed. Collectively, both Grants DE-FGO1-82CE15144 and DE-FGO1-86CE-15301 have been very useful in enhancing the creditability of this project.

The Ph.D. dissertation (Doellner, 1991) is considerably longer than the average Ph.D. dissertation. This is mainly because the dissertation was written to double as a book, either in its existing form or with additions andor modifications depending on the targeted reader audience and publisher(s). Throughout the preparation of this dissertation 
accuracy has been of the highest priority-the same standards will apply to the book. The NBS/OERI Office of Energy-Related Inventions will be acknowledged in this proposed book-in a similar manner as done in the 1991 dissertation.

The proposed book will probably include some additional chapters discussing other aspects of this project. For example, a chapter could be included showing how sophisticated, effective, and ultra-lightweight switching systems can be used for varying the lengths of the photowoltaic-cell series strings. This would compensate for varying photovaltaic-cell temperatures as engine operating conditions change, as discussed in Doeliner, 1991. While these systems are relatively simple, they must be discussed in considerable detail to be fully appreciated.

Another chapter could discuss the environmental aspects of this project. When jet-engine fuel consumption is reduced, carbon dioxide $\left(\mathrm{CO}_{2}\right)$ emissions corresponding decrease (Kandebo, $1991, \mathrm{p} .51$ ). $\mathrm{CO}_{2}$ emissions are believed to play an important role in the undesirable altering of the earth's greenhouse effect ("Is the Earth Warming Up?" 1988, p. 18). 
34

The adaptability and applicability of this project to low $\mathrm{NO}_{x}$ jet engines could also be further discussed.

Yet another chapter could discuss the long-range goal of this project, le., the complete elimination of the accessory drive, and the major advantages expected thereof. While the Ph.D. dissertation is long, all of these aforementioned subjects (chapters) were discussed only relatively lightly in the dissertation. 


\title{
CHAPTER 5
}

\author{
CONCLUSION
}

Automobilies may someday be powered electrically, but aircraft cannot-in general-be powered electrically. In general, aircraft are dependent on oll (petroleum-based fuels) to be powered-with the exception of hydrogen fuel which arguably does not appear promising for aircraft in the foreseeable future. As stated in the NBS Evaluation Report (Burge, 1981, p. 7), this concept (Radiant Energy Power Source for Jet Aircraft) offers "...significant savings to the overall industry." As more and more airlines go bankrupt at the present time, something needs to be done. If the United States of America and other countries are sincerely interested in conserving oll, preserving the environment, and in retaining air superiority, then this project should be of highest national priority. 
Doeliner, 1991 discusses malnly short-term aduantages of this concept. While these advantages are very significant, even greater advantages may result in the long term when the accessory drive is eliminated, as mentloned in Doeliner, 1991. The reason that this toplc was only lightly discussed in the dissertation was because projects of this nature generally need to be addressed and done one step at a time. The elimination of the accessory drive in conjunction with this project is a vast subject by itself. The unheralded potential of these advancements is reason alone for continued research and development of this project.

When nations go shopping for aircraft, the United States of America has the most to offer. Aircraft are the number one net export for the United States. Future utilization of this project will contribute to our nation's well being and greatly enhance the United State's leadership and prestige in the field of aviation. 


\section{LIST OF REFERENCES}

Anderson, J. D., Introduction to Flight, McGraw Hill, New York, 1978.

Burge, H. L., Evaluation Report on Radiant Energy Power Source for Jet Aircraft, National Bureau of Standards: Offlce of Energy-Related Inventions, Evaluation Report No. $12288 / 005673$, November 1981.

Doellner, 0. L., Radiant Eneray Power Source for Jet Aircraft and Missiles, U.S. Patent No. 4,090,359, May 1978.

Doeliner, 0. L., Utilization of Radiant Energy from Gas Turbines and Jet Engines, Graduate Thesis, University of Arizona Library, 1979.

Doellner, 0. L., Radiant Eneray Power Source for Jet Aircraft: Photographs of Full Size Model, Doell Iner Associates; Tucson, Arizona, February 1981 (Revision March 1982).

Doelliner, 0. L., Radiant Energy Power Source for Jet Aircraft: Application to Large Aircraft, Doellner Associates, Tucson, Arizona, May 1981 (Revision March 1982).

Doellner, 0. L., Radiant Eneray Power Source for Jet Aircraft: Gas-Turbine Desion Considerations, Doellner Associates, Tucson, Arizona, March 1983.

Dofllner, 0. L., Radiant Energy Power Source for Jet Aircraft: Combustor Mathematical Modeling, Doellner Associates, Tucson, Arizona, December 1983. 
Doellner, 0. L., Jet-Enqine Combustor Spectral Radiation Measurements Using Fiberoptic Instrumentation System, Final Report DE-FG01-82CE-15144, Doellner Associates, Tucson, Arizona, February 1986.

Doeliner, 0. L., Aircraft Photovoltaic Power-generating System Ph.D. Dissertation, University of Arizona Library, and publication by University Microfilms International, 18 Ann Arbor, Michigan, 1991.

Gunston, B., World Encyclopedia of Aero Engines, Patrick Stephens Limited, Wellingborough, England, 1986.

"Is The Earth Warming Up?" Time Magazine Inc., New York, July 4, 1988.

Kandebo, S. W., "Advanced Combustors Under Development To Cut Emissions In Conventional Engines," Aviation Week \& Space Technolagy, McGraw Hill, New York, Nowember 25, 1991.

National Bureau of Standards, Office of Energy-related Inventions, Evaluation Report on Radiant Energy Power Source for Jet Aircraft, Evaluation Report No. $12288 / 005673$, November 1981.

Omar, M. A., Elementary Solid State Physics, Addison-Wesley, Reading, Massachusetts, 1975.

18 Hardbound cciples of this dissertation are available from University Microfilms International (1-800-521-0600, extension 3879 ) at a current price of about $\$ 66.50$. 

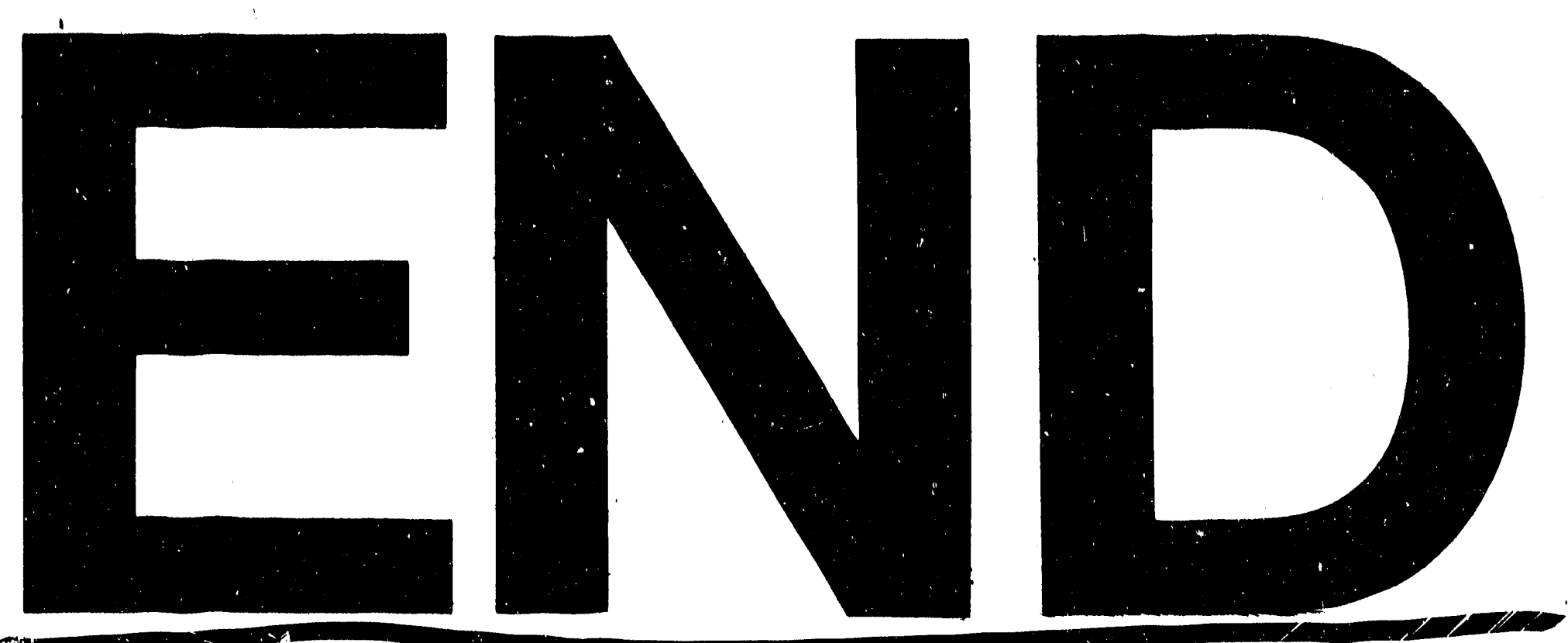

Nin
